\title{
Black Sigatoka disease: new technologies to strengthen eradication strategies in Australia
}

\author{
J. Henderson ${ }^{\mathrm{A}, \mathrm{E}}$, J. A. Pattemore ${ }^{\mathrm{A}}$, S. C. Porchun ${ }^{\mathrm{A}}$, H. L. Hayden ${ }^{\mathrm{B}}$, S. Van Brunschot ${ }^{\mathrm{A}}$, \\ K. R. E. Grice ${ }^{\mathrm{C}}$, R. A. Peterson ${ }^{\mathrm{C}}$, S. R. Thomas-Hall ${ }^{\mathrm{D}}$ and E. A. B. Aitken ${ }^{\mathrm{D}}$ \\ ${ }^{\text {A }}$ Cooperative Research Centre for Tropical Plant Protection, Plant Pathology Building, 80 Meiers Road, \\ Indooroopilly, Qld 4068, Australia. \\ ${ }^{B}$ School of Botany, University of Melbourne, Melbourne, Vic. 3010, Australia. \\ ${ }^{\mathrm{C}}$ Centre for Tropical Agriculture, Queensland Department of Primary Industries and Fisheries, \\ 28 Peters Street, Mareeba, Qld 4880, Australia.

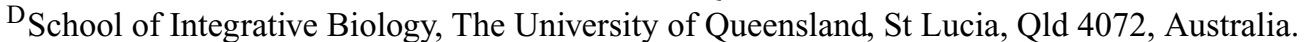 \\ ${ }^{\mathrm{E}}$ Corresponding author. Email: juliane.henderson@dpi.qld.gov.au
}

\begin{abstract}
In 2001, an incursion of Mycosphaerella fijiensis, the causal agent of black Sigatoka, was detected in Australia's largest commercial banana growing region, the Tully Banana Production Area in North Queensland. An intensive surveillance and eradication campaign was undertaken which resulted in the reinstatement of the disease-free status for black Sigatoka in 2005. This was the first time black Sigatoka had ever been eradicated from commercial plantations. The success of the eradication campaign was testament to good working relationships between scientists, growers, crop monitors, quarantine regulatory bodies and industry. A key contributing factor to the success was the deployment of a PCR-based molecular diagnostic assay, developed by the Cooperative Research Centre for Tropical Plant Protection (CRCTPP). This assay complemented morphological identification and allowed high throughput diagnosis of samples facilitating rapid decision-making during the eradication campaign. This paper describes the development and successful deployment of molecular diagnostics for black Sigatoka. Shortcomings in the gel-based assay are discussed and the advantages of highly specific real-time PCR assays, capable of differentiating between Mycosphaerella fijiensis, Mycosphaerella musicola and Mycosphaerella eumusae are outlined. Real-time assays may provide a powerful diagnostic tool for applications in surveillance, disease forecasting and resistance testing for Sigatoka leaf spot diseases.
\end{abstract}

\section{Introduction}

Bananas are the fourth most important food crop of the developing world (Arias et al. 2003), surpassed only by rice, wheat and maize. More than 120 countries produce bananas, with world production estimated to be 103 million tonnes, of which nearly 33 million tonnes are plantains (FAOSTAT 2006). The majority of banana production is for local consumption with only $16 \%$ being traded on the world market (FAOSTAT 2006).

In 2004, Australia produced nearly 311000 tonnes of bananas with a wholesale value estimated to be in the range of AU\$320-350 million (Australian Banana Growers' Council 2006). Australia contributes to less than $0.5 \%$ of world production (FAOSTAT 2006), with all fruit being produced for local markets.

Banana and plantains are monocotyledonous perennial herbs belonging to the genus Musa, of the family Musaceae and order Zingiberales (Jones 2000). All modern cultivars of banana have evolved from intraspecific and interspecific crosses of the two wild diploid species Musa acuminata and Musa balbisiana (Simmonds 1966). Earliest domestication of banana is thought to have occurred in South East Asia and Indochina where the centre of greatest diversity of Musa species exists. This level of diversity has lead to the assumption that South East Asia is the centre of origin of Musa species (Simmonds 1962).

Selection of high-yielding Musa clones and current cultural practices in large-scale monoculture plantations, in and outside the centre of origin of banana, has given rise to the occurrence of a wide range of pests and diseases of fungal, bacterial, viral and parasitic origin. Fungal species within the genus Mycosphaerella cause a number of important leaf spot diseases, with black Sigatoka, caused by Mycosphaerella fijiensis, the most serious 
economic threat. The cost to control black Sigatoka in South American plantations producing bananas for export has been estimated at $25 \%$ of the retail price (Ploetz 2000).

Mainland Australia is currently free of black Sigatoka but since 1981 nine separate incursions of M. fijiensis have taken place in Northern Australia. The pathogen is endemic in parts of the Torres Straits which lies between Papua New Guinea and Cape York Peninsula, Australia. Plant pathologists keep a vigilant watch for incursions which may be brought about by aerial spread of spores or movement of infected plant material. The ability to rapidly detect black Sigatoka and distinguish it from other Mycosphaerella species that also infect banana is vital to be able to eradicate the pathogen in an effective manner. Prior to 1998, conventional methods of diagnosis, including symptomology and morphology, were used to monitor banana crops in Australia for leaf spot diseases. In 1998, molecular assays for black and yellow Sigatoka were added to the arsenal of available diagnostics used by the Queensland Department of Primary Industries and Fisheries (DPI\&F). Based on the polymerase chain reaction (PCR), these assays were introduced to improve the reliability of diagnosis, particularly in situations where fungal structures are not present on leaf tissue for morphological identification, such as after heavy rain.

In this review we describe the disease symptoms and aspects of the disease cycle of black Sigatoka of relevance to incursion management in Australia. We summarise the known global distribution and migration of Mycosphaerella leaf spot diseases on banana and the current disease control methods in Australia, before outlining the development and deployment of molecular diagnostics during a black Sigatoka eradication in Tully, Far North Queensland. Based on the experience gained during application of the test, future approaches to black Sigatoka molecular diagnostics in Australia are discussed.

\section{Mycosphaerella leaf spot diseases and their distribution}

The genus Mycosphaerella contains a number of species which are pathogenic on Musa spp. These include Mycosphaerella musicola, M. fijiensis, M. eumusae and M. musae. The known global distribution of M. musicola, M. fijiensis and $M$. eumusae is shown in Fig. 1. A comprehensive list of locations where yellow and black Sigatoka has been found is available in Jones (2000). Such information for Eumusae leaf spot is not complete as the distribution of this disease is still largely unknown.

\section{Mycosphaerella musicola (causing Yellow Sigatoka)}

Yellow Sigatoka, caused by Mycosphaerella musicola, (anamorph Pseudocercospora musae), was named after an outbreak of the disease in the Sigatoka Valley on the island of Viti Levu in Fiji in 1912 (Meredith 1970). Although previous outbreaks of the disease were reported as early as 1902 in Java (Zimmerman 1902), the name Sigatoka was recorded in the literature. Now referred to as yellow Sigatoka to differentiate it from black Sigatoka, the disease is widespread in most banana production areas of the world including South East Asia, the Pacific, Latin America and Africa (Jones 2000; Mourichon 2003).

Stover (1962) hypothesised that yellow Sigatoka moved from Java to Fiji with planting material and on banana leaves used as packaging material during transport. Following its detection in the Sigatoka Valley in 1912, the disease reached epidemic proportions causing major destruction of plantations. The disease was next detected in Australian banana plantations in 1924, in Surinam and Trinidad in 1934 and, by 1937, had reached most parts of the Caribbean, Central America, Colombia and Venezuela. After a short time, the disease had spread to the neighbouring countries of Brazil (1944), Peru (1946) and Ecuador (1952). Yellow Sigatoka first appeared in Africa in 1938 in Uganda.



Fig. 1. Global distribution of yellow Sigatoka (shaded grey), black Sigatoka ( $)$ and Eumusae leaf $\operatorname{spot}(\boldsymbol{x})$. 
Within 6 months, three more outbreaks in Tanganyika (east African coast) were detected and by 1941, the disease was detected on the west African coast in Cameroon (Stover 1962).

Based on disease records, Stover (1962) hypothesised that the outbreaks of yellow Sigatoka in Africa, South America and Central America were due to ascospores having been carried from Australia westwards on worldwide easterly trade winds. Hayden et al. (2003b) tested Stover's theory of intercontinental dispersal using restriction fragment length polymorphism (RFLP) markers to determine the genetic structure of the global population of M. musicola. To produce an RFLP, genomic DNA of the organism is firstly cut with a restriction enzyme to produce a mixture of fragment sizes. The restricted DNA is separated electrophoretically and then probed with labelled DNA prepared from a region of the fungal genome which is capable of reflecting genetic variation. The result is a DNA banding pattern, or fingerprint, which can be used to assess the relatedness of populations.

Hayden etal. (2003b) postulated that if the intercontinental dispersal theory is correct, alleles found in the Indonesian population of M. musicola would also be present in the Australian, African and Latin AmericanCaribbean populations. Indeed, this genetic prediction was supported by the RFLP data. However, Stover's intercontinental dispersal hypothesis was not supported when the next step of the proposed migration pattern was examined, and the Australian population was compared with the African and Latin American-Caribbean populations. At close to half the loci examined, alleles detected in the Australian population were not found in the African or Latin AmericanCaribbean populations and these two populations contained alleles that were not present in the Australian population. In addition, genetic differentiation data showed the Australian population of M. musicola differed from the African and Latin American-Caribbean populations by $47 \%$ and $54 \%$, respectively. Collectively, these data suggest that the African and Latin American-Caribbean populations arose from the Indonesian population in separate founder events to that of the Australian population. These data have lead Hayden et al. (2003b) to conclude that intercontinental spread via airborne spores from Australia, as proposed by Stover (1962) is improbable and that instead gene flow between continents is likely to have occurred from movement of infected plant material.

The population structure of $M$. musicola within Australia was examined in detail with samples collected in a hierarchical manner at five spatial scales: region, site, plants within a plantation, lesions on a plant, and sporodochia within a lesion (Hayden et al. 2005). RFLP analysis revealed that genotype distribution was highly localised within each population corresponding to isolates sampled from different sporodochia in the same lesion or different lesions on a plant. This result, when considered with the linkage disequilibrium detected in some populations, indicates that conidia of $M$. musicola play a major role in its disease spread. In addition to this, a complex pattern of population differentiation was detected for M. musicola in Australia, possibly reflecting the long presence of the disease in the country. Populations sampled from plantations outside the two major production areas of North Queensland and Southeast Queensland/Northern New South Wales, were genetically very different from all other populations. The low levels of differentiation observed between populations of the two major production areas, despite their geographic separation of over $1000 \mathrm{~km}$, were attributed to the movement of infected plant material during the establishment of commercial plantations over the $>100$ year history of banana production in Australia. Populations sampled outside the major banana production areas in Calen, Ayr and Rollingstone demonstrated high levels of genetic differentiation caused by a lack of gene flow between plantations. These findings together resulted in Hayden et al. (2005) rejecting the hypothesis of large-scale migration between populations of M. musicola in Australia by airborne spores.

\section{Mycosphaerella fijiensis (causing Black Sigatoka)}

In 1963, a more severe leaf spot disease of banana was identified in Fiji (Leach 1964). The disease, known as black leaf streak (BLSD), is caused by Mycosphaerella fijiensis, (anamorph Pseudocercospora fijiensis). In 1972, black Sigatoka was the name given by fieldworkers to describe $M$. fijiensis var. difformis in Honduras (Stover 1980), which was later shown to be morphologically indistinct from M. fijiensis (Pons 1990). The names black Sigatoka and black leaf streak are now used worldwide. In Australia, the name black Sigatoka has been adopted for easy differentiation from the endemic leaf spot disease, yellow Sigatoka.

Pasberg-Gauhl etal. (2000) have presented a comprehensive discussion of the worldwide distribution of black Sigatoka. The first detection of black Sigatoka occurred on the Fijian island of Viti Levu in 1963, only $60 \mathrm{~km}$ from the Sigatoka Valley where yellow Sigatoka was officially first reported (Leach 1964). Following the discovery of the disease in Fiji, a survey conducted between 1964 and 1967 found it to be widespread in the Pacific and parts of the Pacific Rim. These findings indicated that black Sigatoka may have been present in the region long before its identification in Fiji in 1963. The exact distribution of black Sigatoka in Asia is not known. Records indicate the disease is present in Bhutan, China, Indonesia, Malaysia, the Philippines, Singapore, Taiwan, Thailand and Vietnam (Pasberg-Gauhl et al. 2000). However, in some of these regions, attempts to collect new specimens of the disease since their initial record have been unsuccessful. The 
uncertainty in spread may be in part due to emergence of the new disease, Eumusae leaf spot, but also to contributing environmental and host factors occurring at the time of the survey.

Outside of Asia and Oceania, black Sigatoka was next detected in Honduras in 1972 (Stover and Dickson 1976), although it is thought that the disease could have existed there much earlier. In the years leading up to 1981, black Sigatoka reached epidemic proportions in Central America. Spread of the disease into South America began in 1981 and, by 1998 , the disease was present in all Latin American banana growing regions. In the Caribbean, black Sigatoka has been detected in Cuba (1990), Jamaica (1995), the Dominican Republic (1996), Florida (1998), Haiti (1999), Trinidad (2003) and Grand Bahama Island (2004) (Fortune et al. 2005; Jones 2000, 2003; Ploetz 2004). Interestingly, spread of the disease throughout the Caribbean has been slow and Pasberg-Gauhl et al. (2000) attributed this to prevailing easterly winds slowing aerial dissemination of spores to the east. Alternatively, slowed disease spread may be due to a lack of movement of plant material from the banana growing countries to the island nations. There is strong evidence to suggest that the outbreak of black Sigatoka in Jamaica originated from banana fruit shipped from Central America and was not windblown from Cuba as originally thought (Jones 2003).

The history of the distribution and spread of black Sigatoka in Africa, hypothesised to have occurred from the movement of planting material from Asia, has been described (Pasberg-Gauhl et al. 2000). Almost concurrent with the discovery of black Sigatoka in Honduras, an unconfirmed report of the disease was made in Zambia in 1973. The first official record of black Sigatoka in Africa was not until 5 years later in Gabon and the disease spread quickly throughout the West Coast reaching Côte d'Ivoire in 1985. It has been suggested that black Sigatoka reached the East Coast from two sources (Pasberg-Gauhl et al. 2000). The first, from the West Coast via the Democratic Republic of Congo and the second from an outbreak on the island of Pemba which quickly moved via Zanzibar to the coastal regions of Tanzania and Kenya and spread from there. The most recent detection of black Sigatoka in the region was on the island of Madagascar in 2000 (Rivas et al. 2004).

In Australia, black Sigatoka was first detected in 1981 during a plant disease survey of the Torres Straits and Cape York (Jones and Alcorn 1982). Since this initial record, black Sigatoka has been detected in mainland Australia on nine separate occasions (Peterson 2002). At each detection site, the disease has been eradicated using a combination of strategies including plant destruction, fungicide application and replacement of banana plants with more resistant phenotypes. Specific details of the Australian black Sigatoka detections and eradication strategies will be discussed later in this review.
Using RFLP markers, Carlier et al. (1996) found populations of $M$. fijiensis from South East Asia, Africa, Latin America and the Pacific Islands were genetically distinct, showing very high levels of genotypic and allelic diversity. The highest diversity was found to occur in populations from the Philippines and Papua New Guinea (PNG) and over $88 \%$ of alleles detected in Africa, Latin America and the Pacific Islands were also found in South East Asian populations. These results support the hypothesis that M. fijiensis originated in South East Asia before spreading to other regions of the world. Hayden et al. (2003a) conducted a study into the population structure of M. fijiensis in the populations of Australia, PNG and the Pacific Islands to determine gene flow. Hayden et al. (2003a) found populations from the Torres Strait and the Pacific to be more closely related to the PNG population than to each other, suggesting they were founded in separate events from the same source population. Within the Torres Strait region, a moderate level of differentiation $(10 \%)$ was observed between the two populations from Mer Island and Badu Island. Two explanations for the level of differentiation between the two populations are gene flow via long distance ascospore dispersal, which may facilitate the migration of individuals over time, and the movement of infected plant material. The Badu population may have been initiated from the same source as the Mer population (but in a separate event) when bananas on the island were recolonised after the original population was eradicated for quarantine purposes.

\section{Mycosphaerella eumusae (causing Eumusae leaf spot)}

Eumusae leaf spot (ELS) was first described by Carlier et al. (2000) as Septoria leaf spot (anamorph Septoria eumusae). More recently, the anamorph stage of Mycosphaerella eumusae has been reclassified as Pseudocercospora eumusae (Crous and Mourichon 2002). The teleomorph of M. eumusae is morphologically similar to both M. fijiensis and M. musicola (Crous and Mourichon 2002). Musa cultivars showing symptoms of ELS have been identified in Southern India, Sri Lanka, Western Malaysia, Thailand, Vietnam, Mauritius and Nigeria (Carlier et al. 2000). Due to the difficulty in distinguishing M. eumusae from M. fijiensis and M. musicola, this distribution is expected to be far greater than currently reported. Indeed, it is thought that some of the uncertainty surrounding the spread of black Sigatoka in Asia has been complicated by the presence of ELS. Collection of leaf spot samples from, in the first instance, South and South East Asia is required such that the exact spread of ELS may be determined.

\section{Mycosphaerella musae (causing Banana speckle)}

A fourth species of Mycosphaerella which infects banana, causing leaf speckle disease, is Mycosphaerella musae. Banana leaf speckle appears most severely in the cooler 
subtropical regions of Australia. In the rest of the world, the disease is of little economic concern (Jones 2000). Diagnosis of banana leaf speckle based on symptomology is relatively simple as the lesions do not resemble those caused by the other Mycosphaerella spp. infecting banana. For these reasons, Mycosphaerella musae is not focused upon in this review.

\section{Symptomology}

The leaf symptoms of yellow Sigatoka, black Sigatoka and Eumusae leaf spot are very similar and as such are not always a reliable indication of the species present. The developmental stages of lesions for M. musicola and M. fijiensis have been described in detail (Fouré 1987; Klein 1960; Meredith and Lawrence 1969) while a comprehensive description for ELS stages and lesion development has not yet been made.

\section{Disease cycle}

The disease cycles of M. musicola and M. fijiensis are essentially the same and consist of four distinct stages: spore germination, penetration of the host, symptom development and spore production. The disease cycle for M. musicola is shown in Fig. 2. Comprehensive disease cycle descriptions have been made for M. musicola and M. fijiensis (Gauhl et al. 2000; Jones 2000).

\section{Spore germination}

The disease cycle begins when conidia or ascospores germinate on the leaf surface. Germination is highly dependant on moisture and temperature; stomatal penetration by germ tubes occurs when temperatures are above $20^{\circ} \mathrm{C}$ for $2-3$ days and moisture is at near $100 \%$ relative humidity (Stover 1980). M. musicola and M. fijiensis differ in their requirements for moisture during germination: M. musicola requires a film of free water for conidial germination (Leach 1946; Stahel 1937) and 95\% relative humidity for ascospore germination (Brun 1963) whereas $M$. fijiensis requires high relative humidity (92-100\%) for conidial germination and free water for ascospore germination (Jacome and Schuh 1992; Jacome et al. 1991).

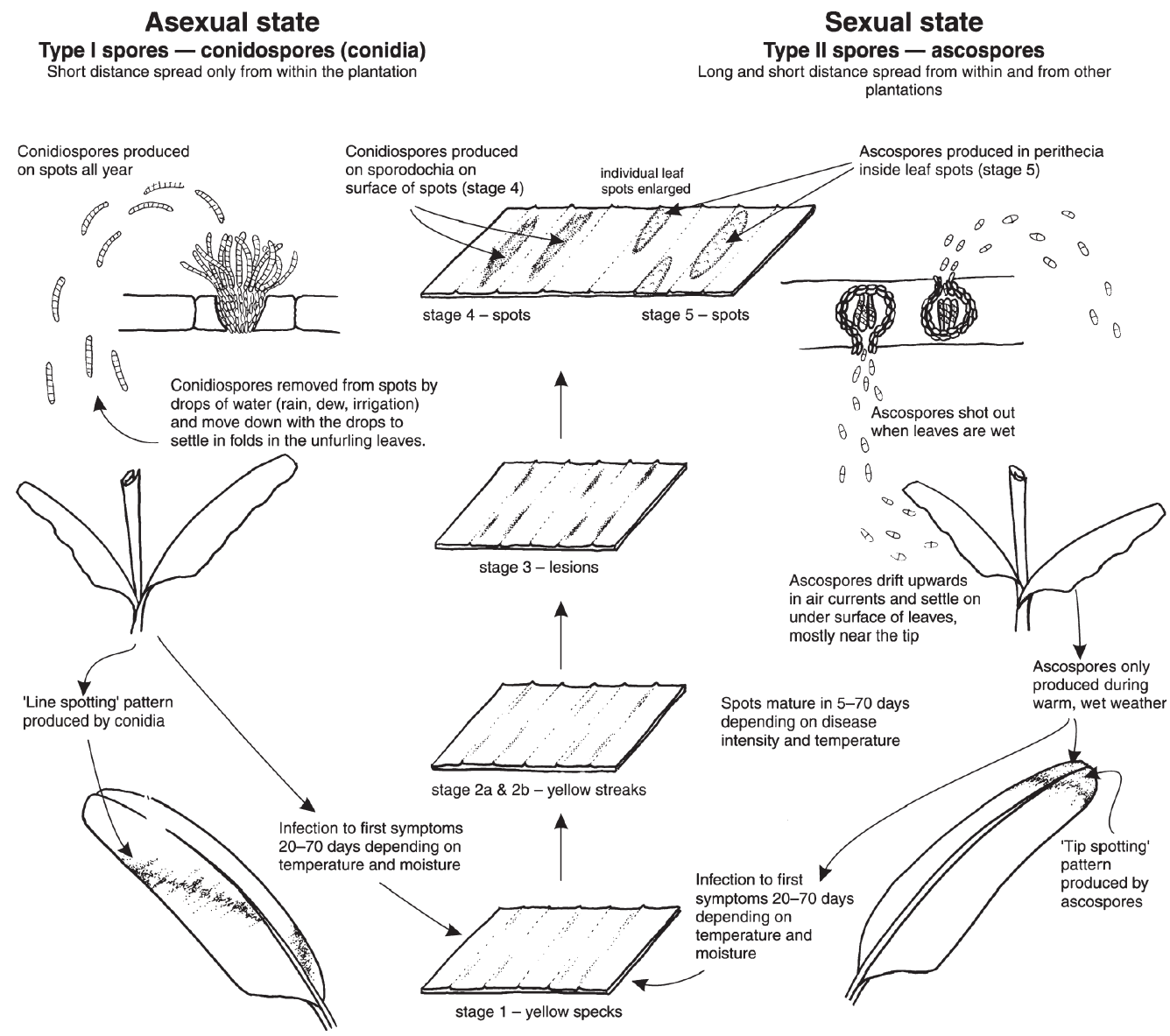

Fig. 2. Disease cycle of Mycosphaerella musicola on banana. Image reproduced with permission of the Queensland Department of Primary Industries and Fisheries. 


\section{Penetration of the host}

After germination, both species undergo a period of epiphytic growth. In M. musicola, this is 2-3 days for ascospore germ tubes (Brun 1963) and 4-6 days for conidial germ tubes (Jones 2000). Subsequently, the germ tube produces an appressorium over a stomatal pore through which the fungus directs a fine, infection hypha (Stahel 1937). The same infection process has been observed for M. fijiensis (Beveraggi 1992) but movement from one stoma to another is much more common for M. fijiensis than M. musicola, eventually resulting in black Sigatoka lesions across entire leaf surfaces (Jones 2000).

\section{Symptom development}

Inside the leaf, the infecting hypha forms a substomatal vesicle. From this vesicle, a hypha grows intercellularly, extending through the mesophyll layers and air chambers into the palisade layer. Once in the palisade layer, the hypha proliferates, growing into the air chambers between the veins (Beveraggi 1992; Stahel 1937). At this stage, the first symptoms become apparent as small yellow specks (M. musicola) or red-brown specks (M. fijiensis).

The time taken between penetration and the appearance of early symptoms is known as the incubation time (Brun 1963; Klein 1960). Gauhl et al. (2000) describe the disease development time as the period between infection and formation of mature spots. Measuring this rate has been found to be more accurate than determining incubation time, in the sense that it does not rely on the detection of subtle symptoms. Disease development time differs between black and yellow Sigatoka, between cultivars and is affected by environmental factors and inoculum levels (Gauhl et al. 2000). Mature spots of black Sigatoka develop more quickly after infection than yellow Sigatoka (Gauhl et al. 2000).

The transition period is the time taken for symptom development from streaks to spots. The duration of the transition period can be affected by several factors, including the level of resistance in the host, environmental conditions and the intensity of the infection (Meredith 1970). Simmonds (1939) and Brun (1963) observed lengthening transition periods for $M$. musicola when temperatures decreased. However, the major factor affecting the transition period is infection intensity. Shorter transition periods were observed for both M. musicola (Leach 1946) and M. fijiensis (Fouré 1987) when inoculum levels increased.

\section{Spore production and dispersal}

Both M. musicola and M. fijiensis are capable of sexual and asexual reproduction, producing ascospores and conidia. Conidia of M. musicola are produced within a sporodochium at the first brown spot, stage 4 of the disease cycle (Brun 1958). Sporodochia are produced on both leaf surfaces within the substomatal air chambers, and the conidiophores grow out through the stomatal pore (Stahel 1937). Conidial production in M. musicola can occur over a wide range of temperatures, provided water is present as dew or rainwater (Simmonds 1939; Stahel 1937). Sporodochia are also capable of producing successive crops of conidia (Calpouzos 1955). Perithecium production is strongly linked to 'wet season' conditions of high rainfall and temperatures greater than $21^{\circ} \mathrm{C}$, and is thus only observed for short periods of the year (Stover 1964, 1968). Spermagonia and perithecia of M. musicola are produced in the final disease stages, when mature lesions start to coalesce and leaf tissue dries out. The production of both spore types is dependant upon moisture and temperature.

Spore production by M. fijiensis differs from M. musicola in both the timing of spore production and the quantities of spores. Conidial production in M. fijiensis occurs at an early stage of lesion development, at stage 2 of the disease cycle (Fouré 1987), and primarily on the lower leaf surface. Smaller quantities of conidia are produced on susceptible cultivars by $M$. fijiensis than M. musicola, and are borne on single or small groups of conidiophores (Stover 1980). Unlike the seasonal production of ascospores in M. musicola, abundant production of $M$. fijiensis ascospores has been observed all year round by Meredith et al. (1973) and Fouré (1987).

The release mechanisms of conidia and the conditions required differ between M. fijiensis and M. musicola. The release of $M$. musicola conidia from the sporodochia requires the presence of water as rain or dew, or may be achieved by buffeting in high winds (Leach 1946). The conidia of M. fijiensis, however, are easily dislodged by wind (Stover 1980). Both species require rain or free water for the ejection of ascospores from perithecia (Stover 1980).

Spore dispersal mechanisms are similar for the two species. Conidia are water dispersed, washed downwards to infect younger plants underneath, or splash-dispersed onto younger leaves above (Meredith 1962; Stover and Fulton 1966). Conidia of M. fijiensis have also been detected in airspora (Burt et al. 1997; Fouré 1987). Ascospores are wind disseminated and can be carried upwards on air currents to younger leaves or dispersed over long distances by laterally moving air currents (Leach 1946; Brun 1963; Fouré 1987).

\section{Current status of Sigatoka leaf diseases in Australia}

Yellow Sigatoka has been present in Australian banana plantations since 1924 (Benson 1925). Yellow Sigatoka is a problem in the tropical areas while banana leaf speckle, caused by Mycosphaerella musae, is a problem in the cooler subtropical plantations of Southeast Queensland and northern New South Wales.

Black Sigatoka is a quarantine pathogen in Australia; the disease poses greater economic, social and cultural threats 
to the banana industry than yellow Sigatoka. Black Sigatoka is significantly more pathogenic than yellow Sigatoka, the major factor being faster disease development. Earlier conidial and higher ascospore production, up to four times more than yellow Sigatoka (Stover 1980), results in greater inoculum levels. In turn, a higher level of disease management, including manual deleafing and an increased number of fungicide applications, is necessary to control the disease.

Black Sigatoka has been detected in Australia nine times since 1981 (Fig. 3). The first detection was in Bamaga, a small Aboriginal and Torres Strait Island community situated $40 \mathrm{~km}$ from the very northern tip of Cape York (Jones and Alcorn 1982). Following this discovery, surveys of all inhabited islands in the Torres Strait as well as mainland communities north of Cooktown, were undertaken. During these surveys, black Sigatoka was recorded on most of the northern and eastern islands in the Torres Strait but was restricted to the Bamaga area on the mainland. It was proposed that the disease had been present for some time in the Torres Strait and that further spread on the mainland was likely to be restricted by: weather conditions (6-8 month dry season), the natural barrier of bush in the



Fig. 3. Locations of black Sigatoka incursions on mainland Australia.
Cape York Peninsula, long distances between properties, small numbers of bananas on the properties, occurrence of more resistant varieties, unfavourable wind direction for spore dispersal and lack of cultural ties between communities in the region.

An attempt to eradicate black Sigatoka to prevent its spread south to commercial growing regions began in October 1981. All infected plants and their regrowth were destroyed and the region was replanted predominantly with Cavendish and Lady Finger varieties. Unfortunately, black Sigatoka reappeared within 12 months and as these varieties were highly susceptible to black Sigatoka, disease levels increased rapidly. The eradication program was declared a failure in 1984. A plant replacement program was introduced in 1987 where all susceptible plants were destroyed and replaced with resistant varieties. This program was successful as only a couple of black Sigatoka lesions were found in 1989 and there were no further recordings until 1999 when the disease was found on small clumps of Cavendish plants at four separate locations. The origin of these detections was traced to three incidents of carryover of regrowth from plants eradicated in 1987 and a single new introduction of Cavendish plants from Thursday Island in 1998. The diseased plants were buried and the area has since remained disease-free (Peterson 2002).

The lessons learned during the Bamaga eradication campaign were applied during subsequent detections. In November 1991, black Sigatoka was found on banana plants in a community garden on an isolated property on the upper reaches of the Pascoe River. All 300 plants on the property were destroyed and replaced with more resistant banana varieties, including Tu8, Bluggoe and Ducasse. The area remains free of black Sigatoka at present (Peterson 2002).

In September 1993, black Sigatoka was found on a property near Ayton in the Bloomfield area, south of Cooktown. Extensive surveys of 1180 properties in the Bloomfield region revealed 650 properties to have banana plants. Ten of these properties contained plants infected with black Sigatoka and 120 properties contained plants infected with yellow Sigatoka. All infected and susceptible plants on properties found to contain black Sigatoka were destroyed and replaced with more resistant varieties. This program was extended to all properties within $50 \mathrm{~km}$ of the initial detections. The pattern of disease incidence observed in Bloomfield indicated a very recent incursion, which facilitated the eradication campaign (Peterson 2002).

In May 1996, black Sigatoka was identified on a banana plant in Weipa. In an intense survey, visits were made to all allotments in Weipa and nearby communities, all properties within $50 \mathrm{~km}$ of Weipa, random surveying of properties in a radius $50-200 \mathrm{~km}$ from Weipa and an aerial survey $250 \mathrm{~km}$ from the township. The survey revealed up to $50 \%$ of 
residential properties to have one or more infected plants, severe infections at two sites and infection on one plant in a semi-commercial block $10 \mathrm{~km}$ from the township. An eradication campaign began and all bananas within a $50 \mathrm{~km}$ radius of Weipa were destroyed. Approximately 8000 plants were removed and buried. The area was checked for the next 3 months to detect infected banana plants and to ensure that regrowth suckers were located and destroyed. The area was replanted with resistant cultivars after 4 months (Peterson 2002).

In June 1997, black Sigatoka was detected on a commercial, organic banana farm. Thirty five hectares of bananas were destroyed on the Daintree River property. These plants were disc-harrowed and ploughed to bury all banana material. All susceptible bananas on other properties within a $7.5 \mathrm{~km}$ radius were also destroyed. No disease was found on any property within a $50 \mathrm{~km}$ radius of the infected farm. The property was checked regularly for regrowth over the next 2 years and in 1999 all quarantine restrictions were lifted (Peterson 2002).

In 1998, black Sigatoka was found on a property in the lower reaches of the Pascoe River, some $35 \mathrm{~km}$ distance from the 1991 detection in Upper Pascoe River. The disease was limited to two sites on one property, with a survey of properties within a $50 \mathrm{~km}$ radius revealing no other detections. All susceptible plants within $5 \mathrm{~km}$ of the infected plants were destroyed and replaced with resistant lines while all resistant plants in this zone were deleafed, leaving only healthy leaf material (Peterson 2002).

Two years later, in 2000, a small number of black Sigatoka infected plants were located on a property in the Upper Daintree Area. Intensive surveying of nearby bananas as well as commercial bananas within a $50 \mathrm{~km}$ radius revealed the infection to be limited to a small stand of newly established plants. These plants were thought to be in the range of 6-12 months old and were located about $100 \mathrm{~m}$ from healthy bananas; both these factors contributed to successful disease containment (Peterson 2002).

In April 2001, black Sigatoka was detected for the ninth time in Australia on a few unmanaged plants near Tully (Peterson 2002). The Tully Banana Production Area (TBPA) is the largest commercial banana growing region in Australia, where about 55\% of North Queensland's bananas are produced. An intensive survey indicated the disease was restricted to the Tully Valley and was likely to be a recent introduction (about 12 months). Over the next 6 months, black Sigatoka was found in samples from 25 properties; 13 from commercial plantings and the remainder from unmanaged plants. An eradication protocol was developed and commenced in September 2001. It consisted of removal of all disease lesions from all commercial banana plantations (4400 ha on 162 blocks), a controlled spray program to prevent reinfection, and the destruction of all unmanaged plants on land parcels in the TBPA. All leaf disease detected was sampled and in the next 12 months, more than 8900 leaf samples were submitted for diagnosis. In May 2002, eradication was completed, and recurrence of the disease was monitored over the next 12 months on all bananas in the TBPA. More than 6300 samples were examined during this phase of the campaign. No black Sigatoka has been detected since November 2001, and using a statistical approach to determine pest free status (Jorgensen et al. 2004), Australia was officially declared free of black Sigatoka in March 2005.

\section{Disease control strategies in Australia}

An integrated approach to control Mycosphaerella pathogens has been adopted in Australian banana plantations incorporating both cultural practices and the application of fungicides. Cultural practices include improved drainage, plant spacing to improve air circulation, selection of plot location away from permanent fixtures or bodies of water that could play a role in infection, and deleafing to reduce inoculum sources. Fungicide application varies according to geographic location. In wetter tropical regions, fungicides are applied 18 to 24 times a year; during the wet season (December-April) fungicides are applied every 10-14 days while in the drier months they are applied every 14-28 days. The protectant fungicide Mancozeb is primarily used, while systemic fungicides such as propiconazole (Tilt, Bumper and Aurora), tebuconazole (Folicur) and benomyl (Benlate) may be applied during the wet season.

In the event of a black Sigatoka detection, a number of measures are implemented to ensure containment of the pathogen. Infected plants are destroyed by ploughing, burying or burning to remove sources of inoculum. In the case of commercial plantations, zero disease levels are maintained for 6-8 months and a weekly spray program consisting of protectant and systemic fungicides for at least 6 months ensures prevention of ascospore release from infected plant remains. Finally, destruction of all non-managed or feral plants is essential.

The effectiveness of an eradication program is heavily reliant on favourable weather conditions. However, even in ideal conditions, success can only be achieved with good cooperation between growers, industry representatives and state agricultural departments. The success of the Tully Banana Production Area eradication strategy was due to such cooperation, combined with unseasonably dry weather conditions between August 2001 and April 2002.

The success of an eradication campaign also relies on early and accurate detection and identification of the pathogen while disease spread is still limited. Correct identification of the species involved is highly important as this determines whether to destroy infected plantations. These two factors, combined with a history of nine incursions of black Sigatoka during the last two decades, highlighted the need for improved surveillance, monitoring and rapid diagnostics in Australia. 


\section{Traditional methods of Sigatoka diagnosis}

Differentiation of black Sigatoka, yellow Sigatoka and Eumusae leaf spot has traditionally been based on leaf symptomology combined with morphological characters of conidial structures. The rate of symptom development can vary with plant age, cultivar and infection density (Jones 2000).

Crous and Mourichon (2002) described the morphological characters used to differentiate the anamorphs of $M$. fijiensis, M. musicola and M. eumusae, but there are a number of drawbacks to this method. The subtle differences in structure require an experienced mycologist/plant pathologist to examine the samples. The limited distribution of M. eumusae and the exotic nature of M. fijiensis to Australia mean that very few plant pathologists have practical experience in distinguishing these diseases on banana. Secondly, the fungal structures required for diagnosis may not be present. Under high rainfall, the asexual structures are washed away and the sample may need 2-3 days incubation to induce conidial production. This was the case in the initial stages of the black Sigatoka incursion in Tully in 2001 where no conidia or conidiophores could be seen on the leaf tissue.

An enzyme-linked immunosorbent assay (ELISA) has been developed to detect Mycosphaerella fijiensis in banana tissue (Melby and Stave 1995). This assay is able to detect the pathogen about 2 weeks earlier than symptombased identification, improving disease forecasting and management strategies. The assay was trialed as a tool to monitor crops for spraying against yellow Sigatoka in North Queensland. However, the ELISA is not specific enough to distinguish the Mycosphaerella species responsible for black and yellow Sigatoka or ELS and is, therefore, not applicable for quarantine pathogen diagnostics of Sigatoka leaf disease in Australia.

\section{Molecular methods for Sigatoka diagnosis}

With the advent of molecular biology in the last two decades, several techniques have been developed which are useful in detecting, identifying and characterising individuals in and between populations. We have already mentioned the use of RFLPs for population studies of M. fijiensis and M. musicola (Carlier et al. 1996; Hayden et al. 2003a, 2003b, 2005). Other molecular-based marker systems which have been developed include PCR-RFLPs for M. fijiensis (an adaptation on RFLPs which does not use labelled probes) (Zapater et al. 2004), and microsatellite markers used in population studies of M. fijiensis (Neu et al. 1999) and M. musicola (Molina et al. 2001).

Both RFLPs and microsatellites are unsuitable as diagnostic markers: RFLPs require large amounts of high quality DNA while microsatellite markers may share sequence homology between closely related species. A diagnostic system for differentiating Mycosphaerella species in a disease outbreak requires a rapid assay that can accurately identify the fungal species causing the leaf spot using infected leaf tissue.

Johanson and Jeger (1993) addressed this task when they developed the first PCR-based diagnostic assay capable of differentiating $M$. fijiensis and M. musicola in infected banana leaf tissue. The assay was designed to the internal transcribed spacer (ITS1) region located between the $18 \mathrm{~S}$ and $5.8 \mathrm{~S}$ subunits of the fungal rDNA (rDNA). Species-specific primers were designed for $M$. fijiensis (primer MF137) and M. musicola (primer MM137), across a polymorphic DNA sequence site that differentiated the two species. In PCR amplification with reverse primer R635, located in the 25S rRNA subunit (Liu et al. 1991), PCR products of about $1000 \mathrm{bp}$ were achieved for both species (Johanson and Jeger 1993). Isolates of M. fijiensis and M. musicola from a range of locations were tested as well as other fungal species known to commonly infect banana, including the closely related pathogens M. musae and M. minima. No crossspecificity was found using the isolates tested. This assay was used to facilitate studies of Sigatoka disease distribution in Uganda (Johanson et al. 2000) and has been used for routine and quarantine testing in many plant pathology laboratories worldwide, including Australia. In 1998, the Queensland Department of Primary Industries and Fisheries (DPI\&F) adopted this PCR-based assay for use during surveillance over 3 years, including three black Sigatoka incursions in 1998, 1999 and 2000. Some shortcomings of the test, such as non-specific amplifications and reduced efficiencies, became apparent during routine diagnosis of Sigatoka leaf spot samples from mainland Australia and the Torres Strait Islands. During its development, the PCR assay was screened against very few isolates from the Oceanic region, causing this level of non-specificity to pass undetected. The proposed centre of origin of M. musicola and M. fijiensis lies very close to Australia and the Torres Straits and thus, higher levels of genetic diversity can be expected from these regions. This situation prompted us to develop improved molecular-based assays for detection of a wider range of isolates and incorporating the sequence diversity found for Mycosphaerella isolates in Australasia.

\section{The Australian Sigatoka diagnostic toolkit}

Prior to 1998, the success of the Queensland DPI\&F banana leaf spot surveillance program relied solely on the mycological and symptom identification skills of its plant pathologists for pathogen identification. From 1998, the DPI\&F adopted molecular-based detection of black and yellow Sigatoka pathogens to complement their diagnostic capability. Today, PCR is an integral component of the surveillance team's diagnostic toolkit, in particular to confirm the identification of samples that cannot be diagnosed using traditional methods; usually around $10 \%$ of banana leaf samples. The number of samples requiring PCR confirmation rose to almost $30 \%$ during the Tully incursion in 2001, due to fungal structures being washed away by heavy rainfall. Tully 
receives in excess of $2400 \mathrm{~mm}$ in rainfall per year (Australian Bureau of Meteorology 2006), mostly between January and April.

In 2000, the team at the CRC for Tropical Plant Protection began development of an improved PCR-based method for differentiation of black and yellow Sigatoka (manuscript in preparation). Over 80 isolates of black and yellow Sigatoka pathogens from Australasia and worldwide were obtained and the ITS1-5.8S-ITS2 section of the rRNA sequenced to identify suitable regions for diagnostic primer design. Additionally, sequences of the same rDNA region were obtained for the closely related pathogens, $M$. musae and $M$. eumusae, as well as other known banana pathogens, including Cladosporium musae, Phaoeseptoria musae, Cordana musae and Cordana johnstonii. Enhancements to the PCR method included new forward primers for $M$. fijiensis and M. musicola, modification of the reverse primer R635 (Liu et al. 1991) and introduction of a hot-start Taq DNA polymerase. A more rapid DNA extraction method (Stewart and Via 1993) and high volume handling equipment were introduced to improve sample throughput. The outcome of these modifications was a more specific and sensitive PCR assay which required only a single DNA template dilution to produce a definitive result requiring no further analysis in $98 \%$ of cases. Overall, throughput of the assay was improved 8 -fold with the results available in less than $9 \mathrm{~h}$ from receipt of a sample.

This PCR assay was used to diagnose banana leaf samples during the Tully 2001 black Sigatoka incursion. Between April 2001 and May 2003, more than 14700 leaf samples from the Tully banana production area and nearby Innisfail and Kennedy areas were examined and a preliminary diagnosis made based on symptomology. Diagnosis for nearly $30 \%$ of these samples was confirmed by PCR. This combination of traditional and molecular diagnostic strategies provided the best outcome for the banana industry. Rapid decisions on eradication and management strategies were possible, and subsequently losses to the industry were kept to a minimum.

The CRCTPP-developed PCR assay was routinely used in surveillance of banana leaf spot pathogens at the Centre for Tropical Agriculture in Mareeba, Queensland between 2001 and 2004. However, during this time, a very small number of false positives $(0.03 \%)$ were detected in more than 15000 samples screened. Cloning and sequencing of the amplification products revealed these isolates to be two occurrences of Phaeoseptoria musae, an isolate showing similarity to Mycosphaerella vespa (infecting eucalypts) and an isolate showing similarity to Mycosphaerella citri (infecting citrus). These were unexpected results, as the level of homology that the diagnostic primers exhibited to the pathogens was not high enough to expect cross-specific amplification. Two possible explanations for such results is loss of integrity of the diagnostic primers, for example degradation during storage, and the presence of a previously undescribed species of Mycosphaerella on bananas.

Although in very low incidence, these false positive results cannot be tolerated in quarantine diagnostics. To address this, as well as the need to accommodate emerging diseases such as Eumusae leaf spot, the CRCTPP developed the nextgeneration diagnostic assays for Sigatoka leaf diseases of banana. These assays offer higher specificity and are based on real-time, fluorescent PCR.

Real-time PCR emerged in the mid-1990s as a promising new method for detection and quantification of RNA and DNA templates (Gibson et al. 1996; Heid et al. 1996). Since this time, the equipment has become more affordable and many laboratories have real time PCR machines in-house. As the need for more sensitive and specific diagnostic tests for plant pathogens has grown, an increasing number of real time PCR assays have emerged in the literature (Bach et al. 2003; McNeil et al. 2004; Schneider et al. 2004). The majority of these diagnostic assays are based on TaqMan hydrolysis probe chemistry (Livak et al. 1995; Heid et al. 1996).

Real-time PCR offers distinct advantages over conventional, gel-based PCR assays. From a diagnostic viewpoint, assay reliability is greatly increased by the introduction of a probing step to the reaction. Assay sensitivity is also greatly increased, with real-time PCR capable of detecting a single template. The risk of false positives from cross-contamination of PCR product is high in a diagnostic laboratory setting. However, the likelihood of contamination is greatly reduced by the closed tube format coupled with pre-amplification enzymatic cleavage of contaminating PCR products (using uracil-D-glycosylase). Finally, the time taken for a result is a fraction of gel-based identification of the amplicon, as post-PCR processing is eliminated.

Real-time PCR is currently being used to assist diagnosis of Mycosphaerella leaf spot diseases in the Australian banana industry. TaqMan MGB probe (Applied Biosystems) assays have been designed to the ITS region for Mycosphaerella fijiensis, Mycosphaerella musicola and Mycosphaerella eumusae (manuscript in preparation). The high copy number of the rDNA target provides optimum assay sensitivity. Thorough knowledge of the ITS DNA sequence from a worldwide collection of Mycosphaerella isolates, and other phytopathogens on banana, ensures target specificity. Each of the probes are designed to the same ITS region and differ by 2 or 3 nucleotides across the probe site; the assays have been fully validated and shown to be robust using a collection of 290 Mycosphaerella isolates from across the world. The assay can be applied to both infected banana leaf tissue samples and pure fungal cultures. Using Mycosphaerella musicola as a model, the TaqMan MGB probe assays have been calibrated to measure spore number. The assays are capable of detecting a single spore and the 
quantitative capacity of the tests has potential applications in both research and disease management.

\section{Conclusions and further research}

Rapid and accurate identification of plant pathogens is essential for effective disease control in an incursion event. Diagnosis of fungal plant pathogens using conventional methods has an inherent high skill requirement, particularly in the areas of mycology and symptom identification. Traditional diagnosis can also be quite time-consuming when lengthy culturing steps are required. Molecular diagnostics require less of a skill base once the assay is developed and validated, and in many cases offer more rapid identification to the species level. Furthermore, they do not rely on the presence of intact fungal structures and can effectively identify heat-inactivated or gamma-irradiated pathogen samples.

A combination of conventional and molecular diagnostic techniques provides the ideal approach to Sigatoka diagnostics. Using symptomology, Sigatoka lesions can be differentiated from other leaf pathogens, although a definitive diagnosis of Mycosphaerella species is more difficult. If asexual structures are present on the leaf surface, a confident diagnosis can be made based on morphology. In the absence of these fungal structures, as can happen in times of high rainfall, molecular techniques are necessary for identification.

Black Sigatoka is a quarantine pathogen in Australia and if it became established in the production areas, it would substantially increase costs, reduce the viability of many growers and increase the use of fungicides. Despite nine incursions since 1981, the Australian banana industry, through a program of surveillance and eradication, remains free of the disease. The eradication of the disease in 2001 provided the industry with their biggest challenge to date, as about $55 \%$ of Australia's bananas are produced in the Tully Banana Production Area. Since November 2001, black Sigatoka has not been found in Tully. However, clauses in the Plant Diseases Act prohibiting interstate movement of bananas to some banana growing areas in Australia significantly delayed declaration of area freedom for the Tully region. As confidence in eradication increased, interstate movement bans gradually rescinded. In February 2005, the lifting of bans preventing interstate movement of bananas from the Tully Banana Production Area into the remaining parts of New South Wales (Australia) cleared the way for the final declaration of area freedom. In March 2005, the National Plant Health Committee granted Pest Free Area status for black Sigatoka in the Tully region, reinstating Australia's status as disease-free.

The Tully eradication proved that the efforts of dedicated growers, scientists and field technicians in combination with favourable environmental conditions could produce success. It also emphasised the importance of good working relationships between scientists, industry and regulatory bodies sharing a common goal.

A cost-benefit analysis of the diagnostic component of the surveillance and eradication strategy in Tully found the availability of a molecular diagnostic assay for black Sigatoka was a significant factor in the decision to eradicate the disease (Agtrans 2004). The success of the eradication cannot be directly attributed to the molecular test; however, it provided a high degree of confidence to both the eradication and diseasefree verification programs. While a large number of factors were considered in the decision to eradicate the disease, the capacity to rapidly and reliably diagnose samples had a significant affect on the decision.

The real-time PCR assays for black Sigatoka, yellow Sigatoka and Eumusae leaf spot disease offer the Australian banana industry the best diagnostic tools available. The assays possess all the essential elements of an effective quarantine diagnostic test and while they are currently used for routine surveillance, the real power of the technology may only be fully realised in an incursion event.

The future of molecular diagnostics for Sigatoka leaf disease will be driven by industry application. The realtime PCR diagnostic assays developed by the CRCTPP are highly amenable to a range of purposes. For instance, the sensitivity offered by real-time PCR may have a role in early detection or disease forecasting, identifying the presence of a pathogen before symptoms develop in regions of the world where black Sigatoka is endemic. Spore arrival may be quickly identified using spore-trapping combined with an assay correlating DNA quantity to inoculum level. By predetermining a threshold value for infection threat, potential outbreaks can be forecast and prevented using the appropriate disease control measures. Schweigkofler et al. (2004) have used real-time PCR and a simple spore-trapping method to detect and quantify conidia from the causal agent of Pine pitch canker, Fusarium circinatum. A similar assay system could be developed for Sigatoka leaf disease in banana. The assay has been calibrated for yellow Sigatoka to determine the amount of DNA correlating to a single spore. Such an assay could assist disease forecasting for yellow Sigatoka resulting in improved management of Australian spray regimes. The same approach could be taken for black Sigatoka and the assay used in countries where the disease is endemic to monitor disease levels and plan spraying regimes. Another application of the real-time tests for yellow Sigatoka, black Sigatoka and Eumusae leaf spot disease, could be in assaying for resistance in varietal testing, especially where the plants appear asymptomatic.

The TaqMan MGB probe assays are compatible with the initiative by the Wageningen University and Plant Research International that is aimed at reducing worldwide pesticide usage in banana production (Eden-Green 2004). This International Banana Action Plan will focus on decreasing pesticide input in control of Mycosphaerella leaf spots and 
Radopholus similis by a minimum of $50 \%$ in the next 10 years. The availability of Sigatoka real time PCR assays will facilitate this program.

\section{Acknowledgements}

This work was funded by Horticulture Australia and the Cooperative Research Centre for Tropical Plant Protection. The authors would like to thank Dr Jean Carlier (CIRAD) for supply of DNA isolates and Ms Sue McKell (CRCTPP) for assistance with map imaging. We thank Dr André Drenth (CRCTPP) for his expert guidance during preparation of this manuscript.

\section{References}

Agtrans (2004) Assessment of representative investments by the CRCTPP over the period 1992 to 2006. Brisbane, Australia.

Arias P, Dankers C, Liu P, Pilkauskas P (2003) 'The World Banana Economy 1985-2002.' (Food and Agriculture Organisation of the United Nations: Rome)

Australian Banana Growers' Council (2006) The Australian Banana Growers' Council. Available at http://www.abgc.org.au (verified 10 February 2006)

Australian Bureau of Meteorology (2006) Australian Bureau of Meteorology. Available at www.bom.gov.au (verified 10 February 2006)

Bach H-J, Jessen I, Schloter M, Munch JC (2003) A TaqMan-PCR protocol for quantification and differentiation of the phytopathogenic Clavibacter michiganensis subspecies. Journal of Microbiological Methods 52, 85-91. doi: 10.1016/S0167-7012(02)00152-5

Benson AH (1925) Leaf spot on bananas. Queensland Agricultural Journal 24, 392-393.

Beveraggi A (1992) Etude des interactions hôte-parasite chez des bananiers sensibles et résistants inoculés par Cercospora fijiensis, agent responsable de la maladie des raies noires. $\mathrm{PhD}$ thesis, Université Montpellier II.

Brun J (1958) Etude sur l'action des fongicides huileux dans la luttre contre la cercosporiose. Note préliminaire. Fruits d'Outre Mer 13, 3-14.

Brun J (1963) La cercosporiose du bananier en Guinee. Etude de la phase ascosporee du Mycosphaerella musicola Leach. PhD thesis, Institute Francais de Recherches Fruitieres Outre Mer.

Burt PJA, Rutter J, Gonzales H (1997) Short-distance wind dispersal of the fungal pathogens causing Sigatoka diseases in banana and plantain. Plant Pathology 46, 451-458. doi: 10.1046/j.13653059.1997.d01-32.x

Calpouzos L (1955) 'Studies on the Sigatoka disease of bananas and its fungal pathogen.' (Aitkens Gardens Research Laboratory: Cienfuegos, Cuba)

Carlier J, Lebrun MH, Zapater MF, Dubois C, Mourichon X (1996) Genetic structure of the global population of banana black leaf streak fungus, Mycosphaerella fijiensis. Molecular Ecology 5, 499-510. doi: 10.1046/j.1365-294X.1996.00116.x

Carlier J, Zapater M-F, Lapeyre F, Jones DR, Mourichon X (2000) Septoria leaf spot of bananas: A newly discovered disease caused by Mycosphaerella eumusae (Anamorph Septoria eumusae). Phytopathology 90, 884-890.

Crous PW, Mourichon X (2002) Mycosphaerella eumusae and its anamorph Pseudocercospora eumusae spp. nov.: Causal agent of eumusae leaf spot disease of banana. Sydowia 54, 35-43.

Eden-Green S (2004) Highlights of the First International Congress on Musa. InfoMusa 13, 32-40.
FAOSTAT (2005) FAO Statistical Databases. Available at http://faostat.fao.org (verified 10 February 2006)

Fortune MP, Gosine S, Chow S, Dilbar A, St. Hill A, et al. (2005) First report of black Sigatoka disease (causal agent Mycosphaerella fijiensis) from Trinidad. Plant Pathology 54, 246. doi: $10.1111 / \mathrm{j} .1365-3059.2005 .01123 . \mathrm{x}$

Fouré E (1987) Varietal reactions of bananas and plantains to black leaf streak disease. In 'Banana and plantain breeding strategies. Proceedings of an International Workshop held in Cairns, Australia, 13-17 October 1986'. (Eds GJ Persley, EA De Langhe) pp. 110-113. (Australian Centre for International Agricultural Research: Canberra)

Gauhl F, Pasberg-Gauhl C, Jones DR (2000) Black leaf streak: Disease cycle and epidemiology. In 'Diseases of Banana, Abacá and Enset'. (Ed. DR Jones) pp. 56-62. (CABI Publishing: Wallingford)

Gibson UEM, Heid CA, Williams PM (1996) A novel method for method for real-time quantitative RT-PCR. Genome Research 6 , 995-1001.

Hayden HL, Carlier J, Aitken EAB (2003a) Genetic structure of Mycosphaerella fijiensis populations from Australia, Papua New Guinea and the Pacific Islands. Plant Pathology 52, 703-712. doi: 10.1111/j.1365-3059.2003.00883.x

Hayden HL, Carlier J, Aitken EAB (2003b) Population differentiation in the banana leaf spot pathogen Mycosphaerella musicola, examined at a global scale. Plant Pathology 52, 713-719. doi: 10.1111/j.13653059.2003.00929.x

Hayden HL, Carlier J, Aitken EAB (2005) The genetic structure of Australian populations of Mycosphaerella musicola suggests restricted gene flow at the continental scale. Phytopathology 95, 489-498.

Heid CA, Stevens J, Livak KJ, Williams PM (1996) Real Time Quantitative PCR. Genome Research 6, 986-994.

Jacome LH, Schuh W (1992) Effects of leaf wetness duration and temperature on development of black Sigatoka disease on banana infected by Mycosphaerella fijiensis var. difformis. Phytopathology 82, 515-520.

Jacome LH, Schuh W, Stevenson RE (1991) Effect of temperature and relative humidity on germination and germ tube development of Mycosphaerella fijiensis var. difformis. Phytopathology 81, 1480-1485.

Johanson A, Jeger MJ (1993) Use of PCR for detection of Mycosphaerella fijiensis and M. musicola, the causal agents of Sigatoka leaf spots in banana and plantain. Mycological Research 97, 670-674.

Johanson A, Tushemereirwe WK, Karamura EB (2000) Distribution of Sigatoka leaf spots in Uganda as determined by species-specific polymerase chain reaction (PCR). In '1st International Symposium on Banana and Plantain for Africa'. (Eds K Craenen, R Ortiz, EB Karamura, D Vuylsteke) pp. 319-324.

Jones DR (2000) 'Diseases of Banana, Abacá and Enset'. (CABI Publishing: Wallingford)

Jones DR (2003) The distribution and importance of the Mycosphaerella leaf spot diseases of banana. In 'Mycosphaerella leaf spot diseases of bananas: present status and outlook. Proceedings of the 2nd International Workshop on Mycosphaerella leaf spot diseases held in San José, Costa Rica, 20-23 May 2002'. (Eds L Jacome, P Lepoivre, D Marin, R Ortiz, R Romero, JV Escalant) pp. 317. (International Plant Genetic Resources Institute: Rome)

Jones DR, Alcorn JL (1982) Freckle and black Sigatoka diseases of banana in Far North Queensland. Australasian Plant Pathology 11, 7-9. doi: 10.1071/APP9820007

Jorgensen K, Cannon R, Peterson R (2004) 'Pest free area guidelines. A case study on Tully banana black Sigatoka.' (Plant Health Australia Ltd and the Department of Agriculture, Fisheries and Forestry: Canberra) 
Klein HH (1960) Control of Cercospora leaf spot of bananas with application of oil sprays based on the disease cycle. Phytopathology 50, 488-490.

Leach R (1946) 'Banana leaf spot (Mycosphaerella musicola) on the Gros Michel variety in Jamaica. Investigations into the aetiology of the disease and the principles of control by spraying.' (Government Printer: Kingston, Jamaica)

Leach R (1964) A new form of banana leaf spot in Fiji, black leaf streak. World Crops 16, 60-64.

Liu Z, Stewart EL, Szabo LJ (1991) Phylogenetic relationships among Cercospora and allied genera on banana based on rDNA sequence comparisons. Phytopathology 81, 1240.

Livak KJ, Flood SJA, Marmaro J, Giusti W, Deetz K (1995) Oligonucleotides with fluorescent dyes at opposite ends provide a quenched probe system useful for detecting PCR product and nucleic acid hybridization. PCR Methods and Applications 4, $357-362$.

McNeil M, Roberts AMI, Cockerell V, Mulholland V (2004) Real-time PCR assay for quantification of Tilletia caries contamination of UK wheat seed. Plant Pathology 53, 741-750. doi: 10.1111/j.13653059.2004.01094.x

Melby JM, Stave JW (1995) ELISA evaluation of banana black Sigatoka disease status. Journal of Clinical Ligand Assay 18, 166-170.

Meredith DS (1962) Some components of air-spora in Jamaican banana plantations. The Annals of Applied Biology 50, 577-594.

Meredith DS (1970) 'Banana leaf spot disease (Sigatoka) caused by Mycosphaerella musicola Leach.' (Commonwealth Mycological Institute: Kew)

Meredith DS, Lawrence JS (1969) Black leaf streak disease of bananas (Mycosphaerella fijiensis): Symptoms of disease in Hawaii, and notes on the conidial state of the causal fungus. Transactions of the British Mycological Society 52, 459-476.

Meredith DS, Lawrence JS, Firman ID (1973) Ascospore release and dispersal in black leaf streak disease of bananas (Mycosphaerella fijiensis). Transactions of the British Mycological Society 60, 547-554.

Molina C, Kaemmer D, Aponte S, Weising K, Kahl G (2001) Microsatellite markers for the fungal banana pathogen Mycosphaerella musicola. Molecular Ecology Notes 1, 137-139. doi: 10.1046/j.1471-8278.2001.00051.x

Mourichon X (2003) Overview of progress and results since the first international workshop on Mycosphaerella leaf spot diseases of bananas in 1989. In 'Mycosphaerella leaf spot diseases of bananas: present status and outlook. Proceedings of the 2nd International Workshop on Mycosphaerella leaf spot diseases held in San José, Costa Rica, 20-23 May 2002'. (Eds L Jacome, P Lepoivre, D Marin, R Ortiz, R Romero, JV Escalant) pp. 11-18. (International Plant Genetic Resources Institute: Rome)

Neu C, Kaemmer D, Kahl G, Fischer D, Weising K (1999) Polymorphic microsatellite markers for the banana pathogen Mycosphaerella fijiensis. Molecular Ecology 8, 513-525. doi: 10.1046/j.1365-294X.1999.00510.x

Pasberg-Gauhl C, Gauhl F, Jones DR (2000) Black Leaf Streak: Distribution and economic importance. In 'Diseases of Banana, Abacá and Enset'. (Ed. DR Jones) pp. 37-42. (CABI Publishing: Wallingford)

Peterson RA (2002) 'Black Sigatoka eradication-controlled management program: Tully banana production area 2001-2002'. (Queensland Department of Primary Industries and Fisheries)

Ploetz RC (2000) Black Sigatoka. Pesticide Outlook 11, 19-23. doi: $10.1039 / \mathrm{b} 006308 \mathrm{~h}$

Ploetz RC (2004) First report of black Sigatoka of banana caused by Mycosphaerella fijiensis on Grand Bahama Island. Plant Disease 88, 772 .
Pons N (1990) Taxonomy of Cercospora and related genera. Sigatoka leaf spot diseases of banana. In 'Proceedings of an international workshop held in San José, Costa Rica, March 28-April 1 1989'.

Rivas GG, Zapater M-F, Abadie C, Carlier J (2004) Founder effects and stochastic dispersal at the continental scale of the fungal pathogen of bananas Mycosphaerella fijiensis. Molecular Ecology 13, 471-482. doi: 10.1046/j.1365-294X.2003.02043.x

Schneider WL, Sherman DJ, Stone AL, Damsteegt VD, Frederick RD (2004) Specific detection and quantification of Plum pox virus by real-time fluorescent reverse transcriptionPCR. Journal of Virological Methods 120, 97-105. doi: 10.1016/j.jviromet.2004.04.010

Schweigkofler W, O'Donnell K, Garbelotto M (2004) Detection and quantification of airborne conidia of Fusarium circinatum, the causal agent of pine pitch canker, from two California sites by using a real-time PCR approach combined with a simple spore trapping method. Applied and Environmental Microbiology 70, 3512-3520. doi: 10.1128/AEM.70.6.35123520.2004

Simmonds JH (1939) Influence of seasonal conditions on the development of Cercospora leaf spot of banana with special reference to the control programme. Queensland Agricultural Journal 52, 633-647.

Simmonds NW (1962) 'The evolution of the bananas.' (Longmans: London)

Simmonds NW (1966) 'Bananas.' (Longmans: London)

Stahel G (1937) Notes on Cercospora leaf spot of bananas (Cercospora musae). Tropical Agriculture (Trinidad) 14, 257-264.

Stewart CN, Via LE (1993) A rapid CTAB DNA isolation technique useful for RAPD fingerprinting and other PCR applications. BioTechniques 14, 748-750.

Stover RH (1962) Intercontinental spread of banana leaf spot (Mycosphaerella musicola Leach). Tropical Agriculture (Trinidad) 39, 327-338.

Stover RH (1964) Leaf spot of bananas caused by Mycosphaerella musicola: factors influencing production of fructifications and ascospores. Phytopathology 54, 1320-1326.

Stover RH (1968) Leaf spot of bananas caused by Mycosphaerella musicola: perethecia and sporodochia production in different climates. Tropical Agriculture (Trinidad) 45, $1-12$.

Stover RH (1980) Sigatoka leaf spots of banana and plantains. Plant Disease 64, 750-755.

Stover RH, Dickson JD (1976) Banana leaf spot caused by Mycosphaerella musicola and $M$. fijiensis var. deformis: a comparison of the first Central American epidemics. FAO Plant Protection Bulletin 24, 36-42.

Stover RH, Fulton RH (1966) Leaf spot of bananas caused by Mycosphaerella musicola: the relation of infection sites to leaf development and spore type. Tropical Agriculture (Trinidad) 43, 117-129.

Zapater MF, Rakotonantoandro A, Cohen S, Carlier J (2004) Polymerase chain reaction-restriction fragment length polymorphism markers for the fungal banana pathogen Mycosphaerella fijiensis. Molecular Ecology Notes 4, 80-82. doi: 10.1046/j.1471-8286.2003.00575.x

Zimmerman A (1902) Uber einige tropischer Kulturpflanzen beobachtete Pilze. II. Zentralblatt für Bakteriologie, Parasitenkunde, Infektionskrankheiten und Hygiene 8, 219. [Abstract].

Received 8 August 2005, accepted 12 December 2005 